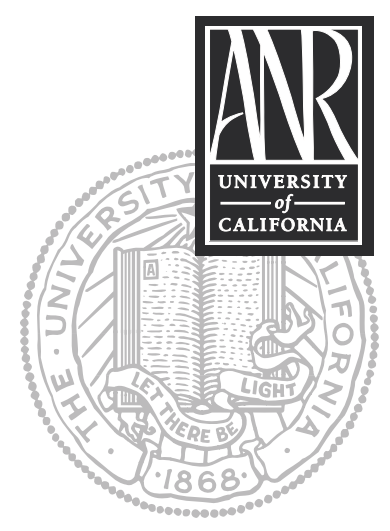

UNIVERSITY OF CALIFORNIA

Division of Agriculture and Natural Resources http://anrcatalog.ucdavis.edu

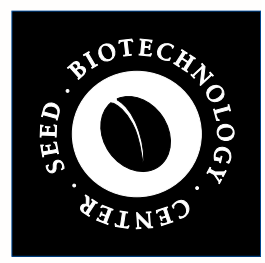

Produced by

Seed Biotechnology Center, UC Davis http://sbc.ucdavis.edu

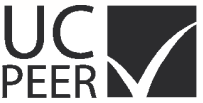

REVIEWED

\section{Crop Biotechnology: Feeds for Livestock}

ALLEN VAN DEYNZE, Biotechnology Specialist, Seed Biotechnology Center, University of California, Davis; KENT J. BRADFORD, Professor of Vegetable Crops and Director, Seed Biotechnology Center, UC Davis; and ALISON VAN EENENNAAM, Cooperative Extension Specialist, Department of Animal Science, UC Davis.

Most crops developed through biotechnology that are on the market today provide farmers with increased convenience and product quality while requiring fewer chemical inputs. According to the USDA Economic Research Service (http://www.ers.usda. gov/data/biotechcrops), herbicide- and insect-resistant biotech varieties accounted for about 85 percent of U.S. soybean acreage and 45 percent of corn acreage in 2003. Livestock eat the meal from approximately 70 percent of the soybeans and consume 80 percent of the corn grain and silage grown in the United States (Etherton et al. 2003), making the livestock industry a major user of biotech crops. Plant breeders are concentrating on enhancing grains or protein sources to produce feedstuffs that will improve feed utilization, performance, product quality, and health of livestock while reducing production costs and environmental impacts. It is likely that biotech crops of the future will play an important role in this arena. This publication discusses potential applications and safety issues associated with such products.

\section{What Is a Biotech Crop?}

A biotech crop is a crop plant that has been genetically engineered using recombinant DNA technology either to promote or to prevent the production of a particular protein, with the objective of introducing or enhancing a desirable characteristic in the plant or seed. Recombinant DNA is DNA formed external to a living cell by joining DNA from two or more different sources (Suslow et al. 2002). Current biotech crops provide resistance to herbicides, diseases, and insect pests. Herbicide-tolerant crops simplify weed control by allowing growers to apply broad-spectrum herbicides without harming the crop. This permits growers to use fewer herbicides and to shift to herbicides that may be more favorable to the environment. Many growers report that herbicide-tolerant crops make it more convenient to adopt minimum tillage or notill practices that reduce soil erosion. Insect-resistant crops reduce pesticide use and therefore are safer for both workers and the environment. Crops that are resistant to viral diseases have also been developed using biotechnology, and crops with modified composition or nutritional properties are currently under development. In 2003, 167 million acres of biotech corn, soybeans, cotton, and canola were grown worldwide, and more than 50 biotech varieties have now been approved for use in various countries (James 2003).

\section{Are Approved Biotech Crops Safe to Eat?}

To be grown commercially, biotech crops must first undergo a formal safety assessment by government authorities in the country in which they are grown. In the United States, the Food and Drug Administration (FDA) is responsible for evaluating whether biotech crops are safe for human and animal consumption (Faust 2002).

The FDA uses the principle of substantial equivalence to assess the safety of biotech-derived crops in food and feed. The biotech crop is compared to its nearest non-biotech counterpart that has a long history of safe consumption (Aumaitre et al. 2002). The only significant difference in composition between the two varieties should be the intended presence or absence of the targeted protein that results in 
the desired characteristic in the biotech plant or seed. A safety evaluation therefore compares the composition of the biotech crop to that of its conventional counterpart in order to establish substantial equivalence. The FDA also examines the properties of the protein made by the introduced gene in the biotech crop for possible toxicity or allergenicity. The evaluation may include assessments on the performance and health of animals fed with the biotech crop. Further safety tests in addition to compositional analyses and animal feeding studies may be recommended, depending on the characteristics of the introduced trait (Kok and Kuiper 2003).

\section{Do Animals Eat Biotech Crops?}

All currently approved biotech crops on the market have been registered for both human food and animal feed use. Prior to approval, feed derived from a biotech crop is analyzed to ensure that it has the same digestibility and nutritional composition as feed from conventional varieties of the same crop (Novak and Haslberger 2000). Numerous scientific studies evaluating animal performance on biotech feed have been performed on beef cattle, swine, sheep, fish, lactating dairy cows, and chickens (see http://www.fass.org/referenc.htm for a comprehensive listing). Several reviews summarizing the results of studies in many species have concluded that animals fed biotech crops show no differences in performance as compared to animals consuming non-biotech varieties of the same crops. (Aumaitre et al. 2002, Clark and Ipharraguerre 2001, Flachowsky and Aulrich 2001). No studies have shown deleterious effects on livestock performance resulting from the consumption of commercially grown, genetically engineered crops.

An unforeseen benefit resulting from feeding of biotech crops has been noted in the case of insect-resistant corn. Molds that often grow at the site of insect damage can produce several fungal toxins, including the deadly fumonisin. Because insectresistant corn sustains less insect damage, it is less susceptible to contamination by these toxins. The resulting corn is safer for both livestock and human consumption (Flachowsky and Aulrich 2002; Munkvold, Hellmich, and Rice 1999; Munkvold, Hellmich, and Showers 1997).

\section{Are Animals that Eat Approved Biotech Crops Safe to Eat?}

Animals digest proteins from biotech crops in the same way as they digest proteins from non-biotech crops. Dietary DNA and proteins are degraded during the digestive process. A number of scientific studies indicate that introduced DNA or proteins from biotech crops are not detected in milk, meat, or eggs from animals that consume feed components derived from these crops (Einspanier et al. 2001; Flachowsky and Aulrich 2002; Phipps, Beever, and Humphries 2002; Phipps, Deaville, and Maddison 2003).

\section{FUTURE BIOTECH CROPS FOR THE LIVESTOCK INDUSTRY}

A new generation of biotech crops designed specifically to benefit the livestock producer is under development (Hartnell 2001). These crops are being engineered with substantial changes in their content of major components (e.g., proteins, amino acids, oils, fatty acids, starches, sugars, fiber) or minor components (e.g., vitamins, minerals, enzymes). As these improved feed crops are designed and intended to be different from non-biotech varieties, they are not expected to be substantially equivalent. Consequently, their approval process will most likely involve additional assessments of their safety for human and animal consumption, as well as extensive documentation of the performance and health of livestock fed with them.

The biotech corn and soybean varieties with increased oil content that are currently under development will provide greater energy intake for beef, swine, and poultry (O'Quinn et al. 2000). High-oil feeds based upon natural genetic variation are 
already available for a limited number of crops, including corn. High-oil corn reduces the amount of feed required for a livestock diet, and this in turn reduces the volume of manure (Etherton et al. 2003). Using biotechnology, scientists may be able to enhance the oil content of crops where there is no natural variation for this trait. Furthermore, conventional high-oil crops often have lower yield or protein content than their loweroil counterparts, whereas traits introduced via biotechnology can modify oil accumulation only at specific growth stages and in targeted tissues to minimize such deleterious effects. Biotech modification of the oil composition of feeds, such as raising the level of oleic acid, may also improve the quality of the resulting animal products for processing and human nutrition (Miller et al. 1990).

Protein content and feeding quality are also being targeted for improvement in biotech crops (Edwards et al. 2000; Molvig et al. 1997). Scientists can modify the protein content of crops either indirectly (by improving nitrogen assimilation) or directly (by modifying key biochemical pathways or introducing proteins with a different amino acid composition). Researchers have produced soybeans and corn with elevated levels of the essential amino acids lysine, methionine, and threonine, and preliminary reports on livestock performance found that consumption of these crops reduced the need for dietary supplementation with protein and amino acids. Similarly, by elevating the levels of sulfur-containing amino acids in lupins, researchers improved the performance of broiler chickens (Ravindran et al. 2002) as well as wool growth and weight gain in sheep (White et al. 2001).

The utilization and nutritional value of feed crops could be enhanced by increasing their digestibility or decreasing undesirable constituents in feed, which may in turn help to reduce the impact of intensive livestock production on the environment. Lignin, which is present in the fibrous portion of plant stems, is often indigestible in non-ruminant animals. High lignin content reduces the efficiency of feed utilization and thereby reduces animal growth. Conventionally bred forage varieties with reduced lignin are available, but they tend to have weaker stems and poor standability in the field. Researchers have developed biotech alfalfa with 20 percent less lignin and 10 percent more cellulose, a combination that makes it more digestible (Marita et al. 2003). As with any new variety, it will need to be evaluated in field trials to determine whether it has any undesirable characteristics. The ability to modify specific components of fiber biosynthesis may allow scientists to develop reduced-lignin forage that is more digestible and still has the stem strength needed for good field performance.

Phosphorus is an essential nutrient that is critical for animal growth and reproduction and in the formation of the animal skeletal system. Much of the phosphorus in corn and other feedstuffs is unavailable to monogastric (single-stomach) animals such as hogs and poultry because it is bound in a complex form called phytic acid (or phytate). As a result, feeds are often supplemented with phosphorus while the phytate is excreted in the manure. The phytate is eventually broken down by soil microorganisms, and this can result in elevated phosphorus levels in lakes and waterways due to run-off from farms. Two ways to decrease phytate excretion are to decrease the phytate content of the feed (Spencer, Allee, and Sauber 2000) and to add the enzyme phytase to the feed in order to break down the phytate complex. Public and private researchers are working on methods for using biotechnology to increase the availability of phosphorus in animal feeds by enabling crops to express fungal or bacterial phytases that can then be blended into feed rations. If successful, these feeds would help the environment by decreasing the phosphorus content of animal waste. 


\section{REFERENCES}

Aumaitre, A., K. Aulrich, A. Chesson, G. Flachowsky, and G. Piva. 2002. New feeds from genetically modified plants: Substantial equivalence, nutritional equivalence, digestibility, and safety for animals and the food chain. Livest. Prod. Sci. 74(3):223-238.

Clark, J. H., and I. R. Ipharraguerre. 2001. Biotech crops as feeds for livestock. Abstr. Pap. Am. Chem. S. 222:U67-U67.

Edwards, H. M., M. W. Douglas, C. M. Parsons, and D. H. Baker. 2000. Protein and energy evaluation of soybean meals processed from genetically modified highprotein soybeans. Poultry Sci. 79(4):525-527.

Einspanier, R., A. Klotz, J. Kraft, K. Aulrich, R. Poser, F. Schwagele, G. Jahreis, and G. Flachowsky. 2001. The fate of forage plant DNA in farm animals: A collaborative case study investigating cattle and chicken fed recombinant plant material. Eur. Food Res. Technol. 212(2):129-134.

Etherton, T. D., D. E. Bauman, C. W. Beattie, C. W. Bremel, G. L. Cromwell, V. Kapur, G. Varner, M. B. Wheeler, and M. Wiedmann. 2003. Biotechnology in animal agriculture: An overview. The Council for Agricultural Science and Technology. Issue Paper 23.

Faust, M. A. 2002. New feeds from genetically modified plants: The U.S. approach to safety for animals and the food chain. Livest. Prod. Sci. 74(3):239-254.

Flachowsky, G., and K. Aulrich. 2001. Nutritional assessment of feeds from genetically modified organisms. J. Anim. Feed Sci. 10:181-194.

Flachowsky, G., and K. Aulrich. 2002. Food of animal origin after feeding of feeds from genetically modified plants (GMP). Ernahrungs-Umschau 49(3):84-88.

Hartnell, G. F. 2001. Potential of biotech crops as livestock feed. Adv. Dairy Technol. 13:249-262.

James, C. 2003. Global status of commercialized transgenic crops. International Service for the Acquisition of Agri-biotech Applications 30.

Kok, E. J., and H. A. Kuiper. 2003. Comparative safety assessment for biotech crops. Trends Biotechnol. 21(10):439-444.

Marita, J. M., J. Ralph, R. D. Hatfield, D. Guo, F. Chen, and R. A. Dixon. 2003. Structural and compositional modifications in lignin of transgenic alfalfa down-regulated in caffeic acid 3-O-methyltransferase and caffeoyl coenzyme A 3-O-methyltransferase. Phytochemistry 62(1):53-65.

Miller, M. F., S. D. Shackelford, K. D. Hayden, and J. O. Reagan. 1990. Determination of the alteration in fatty acid profiles, sensory characteristics, and carcass traits of swine fed elevated levels of monounsaturated fats in the diet. J. Anim. Sci. 68(6):1624-1631. 
Molvig, L., L. M. Tabe, B. O. Eggum, A. E. Moore, S. Craig, D. Spencer, and T. J. Higgins. 1997. Enhanced methionine levels and increased nutritive value of seeds of transgenic lupins (Lupinus angustifolius L.) expressing a sunflower seed albumin gene. P. Natl. Acad. Sci. USA 94(16):8393-8398.

Munkvold, G. P., R. L. Hellmich, and L. G. Rice. 1999. Comparison of fumonisin concentrations in kernels of transgenic Bt maize hybrids and nontransgenic hybrids. Plant Dis. 83(2):130-138.

Munkvold, G. P., R. L. Hellmich, and W. B. Showers. 1997. Reduced Fusarium ear rot and symptomless infection in kernels of maize genetically engineered for European corn borer resistance. Phytopathology 87(10):1071-1077.

Novak, W. K., and A. G. Haslberger. 2000. Substantial equivalence of antinutrients and inherent plant toxins in genetically modified novel foods. Food Chem. Toxicol. 38(6):473-483.

O'Quinn, P. R., J. L. Nelssen, R. D. Goodband, D. A. Knabe, J. C. Woodworth, M. D. Tokach, and T. T. Lohrmann. 2000. Nutritional value of a genetically improved high-lysine, high-oil corn for young pigs. J. Anim. Sci. 78(8):2144-2149.

Phipps, R. H., D. E. Beever, and D. J. Humphries. 2002. Detection of transgenic DNA in milk from cows receiving herbicide tolerant (CP4EPSPS) soyabean meal. Livest. Prod. Sci. 74(3):269-273.

Phipps, R. H., E. R. Deaville, and B. C. Maddison. 2003. Detection of transgenic and endogenous plant DNA in rumen fluid, duodenal digesta, milk, blood, and feces of lactating dairy cows. J. Dairy Sci. 86(12):4070-4078.

Ravindran, V., L. M. Tabe, L. Molvig, T. J. V. Higgins, and W. L. Bryden. 2002. Nutritional evaluation of transgenic high-methionine lupins (Lupinus angustifolius L.) with broiler chickens. J. Sci. Food Agr. 82(3):280-285.

Spencer, J. D., G. L. Allee, and T. E. Sauber. 2000. Phosphorus bioavailability and digestibility of normal and genetically modified low-phytate corn for pigs. J. Anim. Sci. 78(3):675-681.

Suslow, T. V., B. R. Thomas, and K. J. Bradford. 2002. Biotechnology provides new tools for planting. Oakland: University of California Division of Agriculture and Natural Resources, Publication 8043.

http://anrcatalog.ucdavis.edu

White, C. L., L. M. Tabe, H. Dove, J. Hamblin, P. Young, N. Phillips, R. Taylor, S. Gulati, J. Ashes, and T. J. V. Higgins. 2001. Increased efficiency of wool growth and live weight gain in Merino sheep fed transgenic lupin seed containing sunflower albumin. J. Sci. Food Agr. 81(1):147-154.

\section{ADDITIONAL RESOURCES AND INFORMATION ON BIOTECH FEEDS}

Updated references and additional information are available as a resource supplement to this publication at http://sbc.ucdavis.edu/Publications/8145_Supplement.htm 


\section{FOR MORE INFORMATION}

You'll find detailed information on many aspects of biotech crops in these titles and in other publications, slide sets, CD-ROMs, and videos from UC ANR:

Biotechnology Provides New Tools for Plant Breeding, Publication 8043

Roundup Ready Alfalfa: An Emerging Technology, Publication 8153

Genetic Engineering in California Agriculture, video 6502V (VHS) or 6502D (DVD)

To order these products, visit our online catalog at http://anrcatalog.ucdavis.edu.

You can also place orders by mail, phone, or FAX, or request a printed catalog of

publications, slide sets, CD-ROMs, and videos from

University of California

Agriculture and Natural Resources

Communication Services

6701 San Pablo Avenue, 2nd Floor

Oakland, California 94608-1239

Telephone: (800) 994-8849 or (510) 642-2431, FAX: (510) 643-5470

E-mail inquiries: danrcs@ucdavis.edu

An electronic version of this publication is available on the ANR Communication Services Web site at http://anrcatalog.ucdavis.edu.

Publication 8145

(C) 2004 by the Regents of the University of California, Division of Agriculture and Natural Resources. All rights reserved.

The University of California prohibits discrimination or harassment of any person on the basis of race, color, national origin, religion, sex, gender identity, pregnancy (including childbirth, and medical conditions related to pregnancy or childbirth), physical or mental disability, medical condition (cancer-related or genetic characteristics), ancestry, marital status, age, sexual orientation, citizenship, or status as a covered veteran (covered veterans are special disabled veterans, recently separated veterans, Vietnam era veterans, or any other veterans who served on active duty during a war or in a campaign or expedition for which a campaign badge has been authorized) in any of its programs or activities.

University policy is intended to be consistent with the provisions of applicable State and Federal laws.

Inquiries regarding the University's nondiscrimination policies may be directed to the Affirmative Action/Staff Personnel Services Director, University of California, Agriculture and Natural Resources, 300 Lakeside Drive, 6 ${ }^{\text {th }}$ Floor, Oakland, CA 94612-3550, (510) 987-0096. For information about obtaining this publication, call (800) 994-8849. For downloading information, call (530) 754-5112.

pr-12/04-WJC/CR

ISBN 978-1-60107-316-7

To simplify information, trade names of products have been used. No endorsement of named products is intended, nor is criticism implied of similar products that are not mentioned.

This publication has been anonymously peer reviewed for technical accuracy by University of California scientists and other qualified professionals. The review process was managed by the ANR Associate Editor for Animal, Avian, Aquaculture, and Veterinary Sciences. 